\title{
Mechanical Properties of Unidirectional Jute-Polyester Composite
}

\section{Das $\mathrm{S}^{*}$ and Bhowmick $\mathrm{M}$}

Central Institute for Research on Cotton Technology (ICAR), Adenwala Road, Matunga, Mumbai

\begin{abstract}
Unidirectional compressed jute fibre sheets are prepared by using raw jute and jute sliver at $120^{\circ} \mathrm{C}$ for 20 minute, at a pressure of $50 \mathrm{~kg} / \mathrm{cm}^{2}$. Compressed raw jute fibre sheet produced from raw jute reed and jute sliver were used for preparation of the composites in unsaturated polyester resin matrix. Three different fibre content $25(\mathrm{w} / \mathrm{w}) \%, 35$ $(\mathrm{w} / \mathrm{w}) \%, 44(\mathrm{w} / \mathrm{w}) \%$ composites were fabricated by using raw jute and jute sliver. Tensile, flexural, ILSS and SEM properties of composites made from raw jute and jute sliver were studied. The Tensile, flexural and ILSS properties of composites made from raw jute was found to be higher than composites made from jute sliver.
\end{abstract}

Keywords: Composite; Jute; Resin; Flexural; Tensile; ILSS

\section{Introduction}

In a struggle to save our environment, researchers all over the world have been provoked to develop environment friendly composites of the natural fibre. In recent years, use of environment friendly composites is increasing which leads to replacing of natural fibre with inorganic fibres. Natural fibres have many advantages over synthetic fibres as reinforcement material with good specific strength, low cost, lower pollutant emissions; good energy recovery, biodegradable, eco-friendly renewable natural resource [1]. Jute is one of the most important lignocellulosic reinforcement material which is abundantly available in India. Cellulose is the basic component of jute fibre, long cellulosic fibrils embedded in a matrix of hemicelluloses and lignin and form ultimate jute cell. Jute cell is cemented together by lignin so as to form a long filament [2]. Jute plant grows 2.5-4 m in height. Jute fibres are 1 to $3.5 \mathrm{~m}$ long and are separated from the stalk by retting process [3]. The variation of ultimate jute cell length/breadth ratio is observed lengthwise along jute reed from bottom portion to tip portion [4]. Jute is a hydrophilic fibre and most of the common synthetic resins are hydrophobic in nature so fibre-matrix adhesion is poor. Several other disadvantages are low moisture resistance, poor wettability, poor dimensional stability, etc. Some physical, chemical and surface treatments may also be able to eliminate these problems which are described in the literature.

Several researchers have studied the physical and mechanical properties and improvement of mechanical and interfacial properties of jute fibre composites. Roe and Ansel [5] prepared the unidirectional jute composite in polyester resin matrix by the press-molding technique. The calculated fibre strength and modulus were $442 \mathrm{MPa}$ and $55.5 \mathrm{GPa}$, respectively. They reported that polyester resin formed an intimate bond with the jute fibres up to a volume fraction of 0.6 , above which the quantity of resin was insufficient to wet out the fibres completely. Then tensile strength and modulus of jute composite at volume fraction of 0.6 were $250 \mathrm{MPa}$ and $35 \mathrm{GPa}$, respectively. Dash et al. [6] fabricated a low cost jute-polyester composite by using solution impregnation and hot curing methods. They fabricated composites by using both untreated and bleached jute slivers in polyester resin matrix with various percentages. It was observed that tensile and flexural properties of $60 \mathrm{wt} \%$ composites yielded the best results. Saha et al. [7] fabricated jute nonwoven fabric-polyester resin composites. They studied the dynamic mechanical and thermal properties of untreated and chemically modified jute-polyester composites. They reported that much stiffer and stronger composites can be prepared by using partial cyanoethylation of jute fibre. Cyanoethylation jute composites show better creep resistance at comparatively lower temperatures(up to $80^{\circ} \mathrm{C}$ ) whereas a reversed phenomenon is observed at higher temperatures $\left(120^{\circ} \mathrm{C}\right.$ and above). Ray et al. [8] treated jute fibres with $5 \% \mathrm{NaOH}$ solution for four different time periods $(2,4,6$ and $8 \mathrm{~h})$ and prepared jute composites in vinyl ester resin matrix. They reported that alkali treatment leads to improvement in the flexural strength and modulus of composites. They also reported that maximum improvements in the composite properties were observed with $4 \mathrm{~h}$ alkali-treated fibres. Gassan and Bledzki $[9,10]$ reported that the treatment of the isometric jute yarns with $25 \% \mathrm{NaOH}$ for 20 min resulted in an improvement of $120 \%$ and $150 \%$ in the tensile strength and modulus of the jute yarn. They reported a $60 \%$ improvement in the jute-epoxy composite's tensile properties, reinforced with these treated yarns. Tripathi et al. [11] studied the comparison of mechanical properties of juteepoxy composites prepared by using untreated jute filament, sliver jute filament, bleached jute filament and mercerized jute filament as reinforcement.

Gowdaa and Naidu [12] studied the mechanical properties of woven jute fabric-reinforced polyester resin composites. Semsarzadeh et al. [13] studied the tensile strengths and impact energies of jute fibrereinforced polyester composites. Doan et al. [14] studied the physical properties of jute - polypropylene composites and effect of maleic anhydride coupling agent on the properties of composite. Carvalho [15] investigated tensile and impact properties of different fabric style jute-polyester composites. He reported that plain weave jute composite have higher tensile strength than knitted jute composite and tensile strength of knit weave composite is independent of direction of test. Khan et al. [16] investigated effect of gamma and UV radiation on mechanical properties of $38 \mathrm{wt} \%$ fibre content jute-polyester composite. They enhanced tensile strength to $108 \%$ and bending strength to $58 \%$ of jute-polyester composites. They produced $2 \mathrm{~mm}$ thick polymer film by using mixture of 2-hydroxy ethyl methacrylate and aliphatic urethane diacrylate oligomer polymer on jute fabric. They used Co-60 gamma radiation for producing the polymer film on jute fabric as well as curing the composite. They modified surface of the bleached jute fabric by

*Corresponding author: Das S, Scientist, Central Institute for Research on Cotton Technology (ICAR), Adenwala Road, Matunga, Mumbai 400019, Tel: 24127273, E-mail: sekhar.tex@gmail.com

Received March 26, 2015; Accepted June 24, 2015; Published July 30, 2015

Citation: Das S, Bhowmick M (2015) Mechanical Properties of Unidirectional JutePolyester Composite. J Textile Sci Eng 5: 207. doi:10.4172/2165-8064.1000207

Copyright: () 2015 Das S, et al. This is an open-access article distributed under the terms of the Creative Commons Attribution License, which permits unrestricted use, distribution, and reproduction in any medium, provided the original author and source are credited. 
using 254-133 nm UV radiation. They increased tensile strength to $150 \%$ and bending strength to $90 \%$ by using UV radiation. Khan and his team [17] studied mechanical, thermal, water uptake properties of jute fabric-gelatin bio composites. They reported that $50 \mathrm{wt} \%$ fibre content yielded the best results. They also reported that the tensile strength, tensile modulus, bending strength, bending modulus and impact strength of the $50 \mathrm{wt} \%$ jute fabric-gelatin composites were $85 \mathrm{MPa}$, $1.25 \mathrm{GPa}, 140 \mathrm{MPa}, 140 \mathrm{MPa}$ and $9 \mathrm{GPa}$ and $9.5 \mathrm{~kJ} / \mathrm{m} 2$, respectively. Sultana et al. [18] fabricated $35 \mathrm{wt} \%$ jute- polypropylene composites by using sodium Periodate oxidised raw Jute fibres. They reported an improvement of interfacial adhesion and bonding between the fibre and matrix and reduction of water absorption properties. Reddy [19] fabricated fully biodegradable jute composite in soy protein matrix and compared the mechanical properties with jute polypropylene composites. He reported that tensile and flexural properties of jute-soy protein are much higher than jute - polypropylene composites. Behera et al. [20] studied the physical properties of jute-nanoclay modified soy resin composite. Saw et al. [21] fabricated the jute-coir hybrid composites by using epoxy novolac resin and tested different physical properties of this composite.

Raw jute and jute sliver are voluminous materials so it is very difficult to fabricate composite by hand lay-up technique. In the excess resin extraction process for composite preparation, the jute fibres also come out with the extracted resin. In this study an innovative method was applied to avoid this difficulty. Jute fibre sheet was produced which is a compact form of the fibre. Mechanical properties such as tensile, flexural, ILSS and SEM of the composites made from raw jute and jute sliver were compared.

\section{Experimental}

\section{Materials}

The raw jute fibre reeds (TD-3 grade) from same bale were collected from local market in Kolkata, India. Unsaturated polyester resin manufactured by Swastik Interchem Pvt. Ltd. was purchased from Mumbai's local market. Cobalt octoate (accelerator) and methylethyl-ketone peroxide (initiator) manufactured by Triveni Interchem Pvt. Ltd. also used and these were purchased from Mumbai.

\section{Composite fabrication}

Raw jute fibre reed of TD-3 grade (C. olitorius) was selected for producing jute sliver and jute fibre sheet. One portion of raw jute is used for producing raw jute fibre sheet and other portion is used to produce jute sliver. For producing jute sliver, raw Jute fibre reed was sprayed with $30 \%$ jute batching oil in water emulsion $(2 \%$ oil on the weight of fibre) and the material was kept in a closed chamber for 24 hours. Then it was passed through a softener machine for softening the jute fibre. The soften fibres were then successfully passed through breaker card followed by a finisher card.

Raw jute fibre reed and jute sliver are voluminous so it is difficult to handle the reinforcing material during composite fabrication by hand layup technique. For producing compressed jute sheet, unidirectional raw jute fibre reeds and sliver were laid out by hand on a smooth steel plate. Then little amount of water was sprinkled on jute fibre and it was covered by a smooth steel plate and kept it in hot press at $120^{\circ} \mathrm{C}$ for 20 minute, at a pressure of $50 \mathrm{~kg} / \mathrm{cm}^{2}$ for getting uniformly compressed unidirectional jute sheet. In this process the fibre volume is reduced as the trapped air inside the fibre is forced out to get a compressed jute fibre sheet. Unidirectional jute fibre sheet-polyester resin composites were prepared by hand lay-up technique. The first coat of the resin formulation $[\text { resin }+2 \% \text { accelerator (o.w.r. })^{*}+2 \%$ catalyst (o.w.r. $\left.)^{\star}\right]$ was smeared on the polyester sheet which was kept on a smooth steel plate. Polyester sheet was used for quick and easy removal of the composite from the mould. A single fibre sheet was placed on top of the resin. Again resin was applied on the fibre sheet by using a brush. The next fibre sheet layer was placed on top of the first layer and the above process was repeated. After the final layer of fibre sheet was laid out, it was covered with a polyester sheet. The steel roller was used to even out the resin and to remove any entrapped air in the resin. A flat smooth steel plate was placed on top of polyester sheet to ensure a smooth surface. A compressive pressure of $5 \mathrm{~kg} / \mathrm{cm}^{2}, 25 \mathrm{~kg} / \mathrm{cm}^{2}$ and $35 \mathrm{~kg} / \mathrm{cm}^{2}$ were applied on the mould to produce $25(\mathrm{w} / \mathrm{w}) \%, 35$ (w/w)\% and 44 (w/w)\% composite respectively, at the time of curing. The specimens were also post cured at $70^{\circ} \mathrm{C}$ for $2 \mathrm{~h}$ after removal from the mould.

The composite samples having fibre content $25(\mathrm{w} / \mathrm{w}) \%, 35 \mathrm{w} / \mathrm{w}) \%$ and $44(\mathrm{w} / \mathrm{w}) \%$ obtained from the raw jute were labelled as RJ25C, RJ35C and RJ44C. Accordingly, sliver jute composites having the fibre content $25(\mathrm{w} / \mathrm{w}) \%, 35(\mathrm{w} / \mathrm{w}) \%$ and $44(\mathrm{w} / \mathrm{w}) \%$ were labelled as SJ25C, SJ35C and SJ44C, respectively.

\section{Fibre fineness and bundle strength measurements}

Jute fibre bundle strength and fineness were measured using "JTRL bundle strength tester" and "JTRL fibre fineness tester". Fibre fineness was measured by airflow method.

\section{Mechanical testing}

Tensile and flexural test: Tensile tests along with the fibre direction were carried out with ASTM D3039 for polyester and composite samples of $500 \mathrm{~mm}$ long, $15 \mathrm{~mm}$ wide and $4 \mathrm{~mm}$ thick in a universal testing machine (Instron) in order to determine the tensile properties. Test speed was $5 \mathrm{~mm} / \mathrm{min}$. Three point bend tests along with fibre direction were also performed in a universal testing machine (Instron) in accordance with ASTM D790 to measure the flexural strength of the polyester resin and composite samples. Test specimens having 150 mm length, width of $25 \mathrm{~mm}$, thickness of $4 \mathrm{~mm}$ and a loading span of $64 \mathrm{~mm}$ was employed. The support span/specimen thickness ratio was $16: 1$ and the crosshead speed of $2 \mathrm{~mm} / \mathrm{min}$. Five samples were tested for both tensile and flexural strength.

Interlaminar shear strength:The short beam shear tests were carried out in a universal testing machine (Instron) in accordance with ASTM D2344-84 to evaluate inter-laminar shear strength (ILSS). The support span/specimen thickness ratio was 5:1 and cross head speed was $2 \mathrm{~mm} / \mathrm{min}$

Five samples from each type of composites were tested for their mechanical properties and the data regarding their mechanical tests were expressed as mean \pm standard deviation.

\section{Electron microscopy}

Fractured surfaces of the composites and the morphology of different fibres were studied with a Philips XL 30 scanning electron microscope (SEM) with an acceleration voltage of $10 \mathrm{kV}$. The sample surfaces were sputter coated with gold to avoid charging.

\section{Results and Discussion}

Raw jute fibre used for composite preparation was tested for fineness and bundle strength and are given in Table 1. Single jute fibre fineness was found to be 2.7 tex and the bundle strength of the jute fibres was $21.04 \mathrm{~g} / \mathrm{tex}$. 
Citation: Das S, Bhowmick M (2015) Mechanical Properties of Unidirectional Jute-Polyester Composite. J Textile Sci Eng 5: 207. doi:10.4172/21658064.1000207

\begin{tabular}{|l|r}
\hline Fineness (tex) & 2.70 \\
\hline
\end{tabular}

Bundle Strength (gm/tex)

21.04

Table 1: Bundle strength and fibre fineness of raw jute fibre.

\begin{tabular}{|c|c|c|c|c|c|c|c|}
\hline Material & $\begin{array}{c}\text { Tensile strength } \\
\text { (MPa) }\end{array}$ & $\begin{array}{c}\text { Tensile modulus } \\
\text { (GPa) }\end{array}$ & Tensile Strain (\%) & $\begin{array}{l}\text { Flexural strength } \\
(\mathrm{MPa})\end{array}$ & $\begin{array}{l}\text { Flexural modulus } \\
\text { (GPa) }\end{array}$ & $\begin{array}{c}\text { Flexural Strain } \\
(\%)\end{array}$ & $\begin{array}{c}\text { ILSS } \\
\left(\mathbf{N} / \mathbf{m m}^{2}\right)\end{array}$ \\
\hline Polyester resin & $25 \pm 7.31$ & $0.95 \pm 0.21$ & $4.6 \pm 0.18$ & $31.5 \pm 10.59$ & $3.88 \pm 1.05$ & $2.01 \pm 0.59$ & $0.94 \pm 0.32$ \\
\hline RJ25C & $80 \pm 13.39$ & $3.68 \pm 0.48$ & $4.5 \pm 0.55$ & $102 \pm 16.23$ & $9.42 \pm 1.31$ & $2.27 \pm 0.15$ & $12.79 \pm 3.01$ \\
\hline RJ35C & $106 \pm 16.30$ & $4.83 \pm 0.63$ & $5.2 \pm 0.83$ & $124 \pm 17.97$ & $11.6 \pm 1.65$ & $3.49 \pm 0.28$ & $10.87 \pm 1.51$ \\
\hline RJ44C & $122 \pm 31.11$ & $5.56 \pm 0.67$ & $4.8 \pm 0.54$ & $145 \pm 21.94$ & $15.41 \pm 2.22$ & $3.18 \pm 0.31$ & $10.18 \pm 0.62$ \\
\hline SJ25C & $71 \pm 11.93$ & $3.24 \pm 0.65$ & $4.8 \pm 0.59$ & $85 \pm 20.16$ & $7.56 \pm 1.36$ & $2.61 \pm 0.60$ & $9.48 \pm 1.29$ \\
\hline SJ35C & $89 \pm 9.74$ & $4.46 \pm 0.45$ & $5.4 \pm 0.48$ & $103 \pm 14.64$ & $10.64 \pm 1.41$ & $2.66 \pm 0.57$ & $8.45 \pm 1.71$ \\
\hline SJ44C & $109 \pm 16$ & $4.89 \pm 0.55$ & $4.7 \pm 0.54$ & $112 \pm 17.30$ & $13.24 \pm 2.12$ & $2.57 \pm 0.48$ & $8.95 \pm 0.93$ \\
\hline
\end{tabular}

Table 2: Comparison of mechanical properties of the composites made from raw jute and jute sliver.
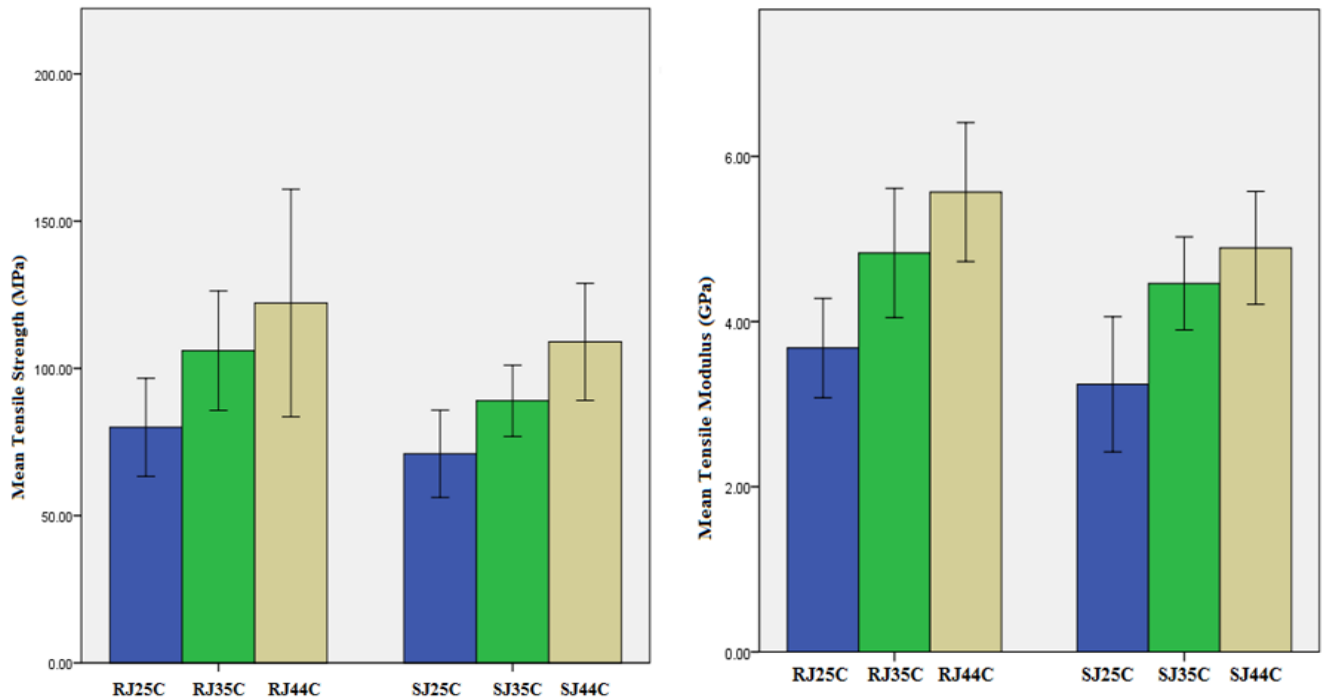

Figure 1: Comparison of tensile strength and modulus for six different types of composites.

\section{Mechanical properties of polyester resin}

Samples were prepared for tensile and flexural property determination of polyester resin for comparison purpose. It was found that the resin had a tensile strength of $25 \mathrm{MPa}$ and tensile modulus of $0.95 \mathrm{GPa}$. The flexural strength of the cast resin was $31.5 \mathrm{MPa}$ with flexural modulus of $3.88 \mathrm{GPa}$.

\section{The tensile properties of the composite samples}

Tensile, flexural and ILSS properties of the resin and composite samples are reported in the Table 2.

Samples were prepared for tensile property determination of polyester resin for comparison purpose. It was found that the resin had a tensile strength of $25 \mathrm{MPa}$ and tensile modulus of $0.95 \mathrm{GPa}$.

It is well known that composite strength properties are mainly dependent on fibre loading (\%), fibre strength and interfacial strength between fibre and matrix. Mechanical properties of composite give some indirect information about interfacial bonding between fibre and matrix. Figure 1 indicates the effect of increasing of fibre content to tensile properties of jute-polyester composites. For both raw and sliver jute composites show tensile strength and modulus increase with fibre loading percentage. It has been observed from the Table 2 that, RJ44C had tensile strength $15 \%$ higher than RJ35C and $52.5 \%$ higher than RJ25C composites and RJ35C had 32.5\% higher tensile strength than RJ25C. Tensile modulus (5.56 GPa) of RJ44C was higher than RJ35C $(4.83 \mathrm{GPa})$ and RJ25C (3.68 GPa).

It has been also observed from the Table 2 that, SJ44C had tensile strength $22.4 \%$ higher than SJ35C and 53.5\% higher than SJ25C composites and SJ35C had 25.3\% higher tensile strength than SJ25C. Tensile modulus ( $4.89 \mathrm{GPa}$ ) of SJ44C was higher than SJ35C (4.46 GPa) and SJ25C (3.24 GPa) Figure 2.

The tensile strength and modulus of raw jute composites had higher than sliver jute composites. R25C, R35C and R44C had 11.2\%, $19.1 \%$ and $11.9 \%$ higher tensile strength than S25C, S35C and S44C and tensile modulus. Figure 3 of raw jute composites were also higher than sliver jute composites.

\section{Flexural properties of jute composites}

Flexural strength and modulus of a composite is dependent on the fibre strength and extreme layer of reinforcement plays a vital role. The crack always initiates on the tension side of the composite 

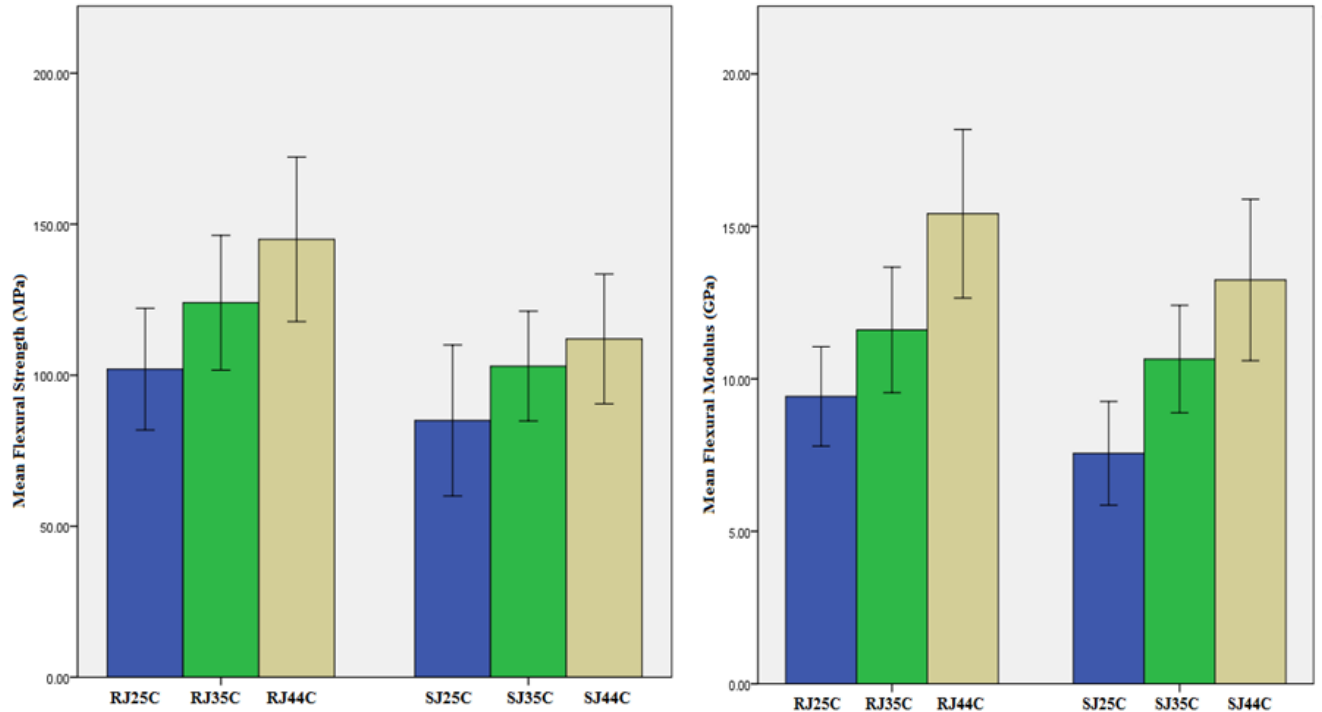

Figure 2: Comparison of flexural strength and modulus for six different types of composites.
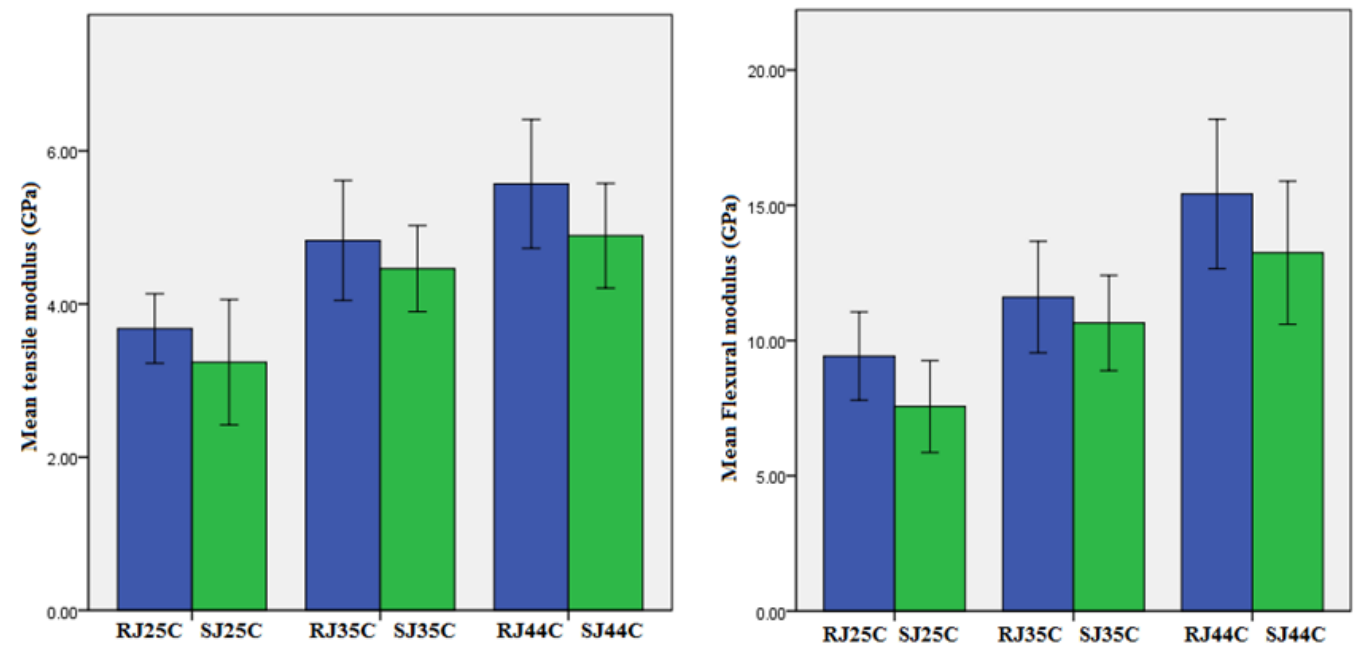

Figure 3: Comparison of tensile and flexural modulus of composites made from raw jute and jute sliver.

sample and slowly propagates in an upward direction. Normally, the flexural modulus is very sensitive to the matrix properties and fibrematrix interfacial bonding [21]. It has been observed from the Table 2 that, polyester resin had flexural strength and modulus of $31.5 \mathrm{MPa}$ and $3.88 \mathrm{GPa}$. Figure 2 indicates that flexural strength and modulus is directly proportional to fibre content of jute composites. From Table 2 , it has been observed that RJ44C composite samples had $16.9 \%$ and 42.1\% higher flexural strength than RJ35C and RJ25C composite samples and RJ35C had 21.55\% higher flexural strength than RJ25C. Flexural modulus is also increased with fibre loading percentage, RJ44C $(15.41 \mathrm{GPa})$ has higher modulus than RJ35C (11.6 GPa) and RJ25C $(9.42 \mathrm{GPa})$. The same trend is also observed for jute sliver composites, SJ44C had $8.7 \%$ and $31.7 \%$ higher flexural strength than SJ35C and SJ25C, respectively and SJ35C had $21.1 \%$ higher flexural strength than SJ25C. Flexural modulus (13.24 GPa) of SJ44C was higher than SJ35C
(10.64 GPa) and SJ25C (7.56 GPa). The flexural strength and modulus of raw jute composites were higher than sliver jute composites. R25C, R35C and R44C had 20\%, 20.3\% and 16.9\% higher tensile strength than S25C, S35C and S44C and flexural modulus. Figure 3 of raw jute composites were also higher than sliver jute composites.

\section{Interlaminar shear strength}

Short beam shear test is an effective method for explaining interfacial adhesion property of a composite. It is a 3-point short span length bend test, which generally create failure by inter-laminar shear. A large span length in bending test increases the maximum normal stress without affecting the inter-laminar shear stress and thereby increases the tendency for longitudinal failure. Inter-laminar shear failure initiated and propagated only when the span length is short. Maximum shear stress is observed in a beam at the mid-plane. So in 


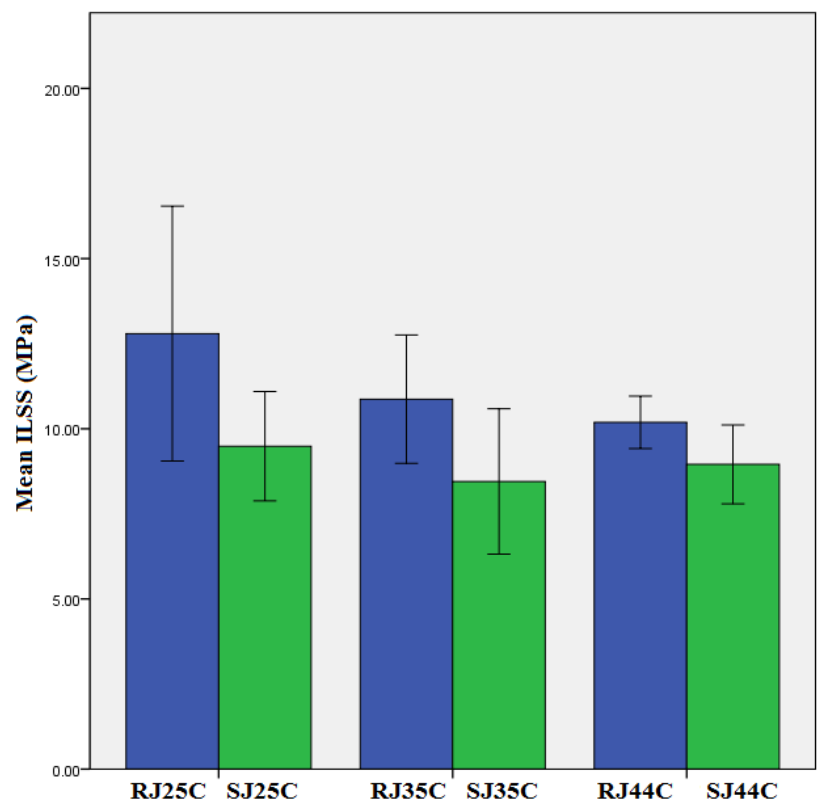

Figure 4: Comparison of ILSS properties for six different types of composites.

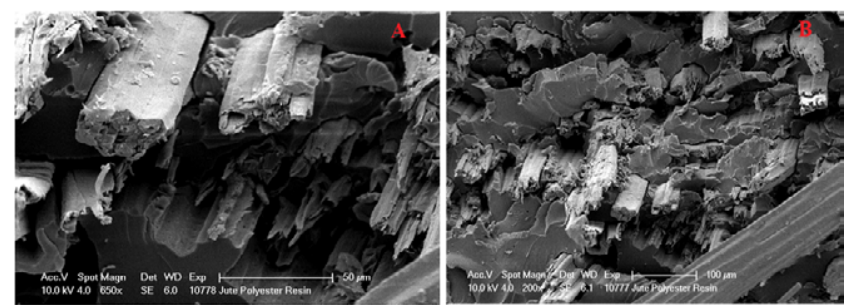

Figure 5: SEM micrograph of failure surface of the composites made from raw jute $(A)$ and jute sliver (B).

short the shear test of failure determination consists of a crack running along the mid-plane of the beam so that crack plane is parallel to the longitudinal plane.

Interlaminar shear strength (ILSS) properties of the resin and composite samples are reported in the Table 2 which indicates that composites made from raw jute had higher ILSS strength than sliver jute composites for the three percentages of composites.

Figure 4 indicates comparison of ILLS properties of same fibre content composites with two types of composites. It was observed that composite made from raw jute have higher ILLS than sliver jute composites, for $25(\mathrm{w} / \mathrm{w}) \%, 35(\mathrm{w} / \mathrm{w}) \%$ and $44(\mathrm{w} / \mathrm{w}) \%$ fibre content composites.

Tensile strength, tensile modulus, flexural strength, flexural modulus and ILLS properties of jute composite made from raw jute was higher than composite made from jute sliver. The probable reason behind this is that raw jute fibre sheet has more oriented fibres than jute sliver. Jute sliver contain jute batching oil ( $2 \%$ oil on the weight of fibre) which affect bonding between fibre and polyester matrix.

\section{Structural analysis of the composite samples}

To study the structural morphology and to observe the failure structure of the composite samples scanning electron-microscopy was used to observe the failure surface after flexural failure of the samples. The SEM micrographs of the samples from raw jute are given in Figure 5.

It can be observed that the SEM micrographs clearly shows that the resin has penetrated the jute mats used as reinforcement material and it has totally surrounded each and every fibre. So, this signifies that the above mentioned process of composite preparation can be used for increasing fibre reinforcement percentage without compromising composite quality.

\section{Conclusion}

In this research a new method for production of compressed raw jute and jute sliver sheets preparation is described, which can be used as the reinforcement material to improve fibre percentage in composites produced. Among the two types of starting material, i.e., raw jute and jute sliver, it can be concluded that the composites made from raw jute have higher tensile and flexural properties compared to the composites made from jute sliver. ILSS properties of jute composite made from raw jute are also better than composite made from jute sliver. Jute fibre sheet would be economical than commonly used reinforcement material such as jute fabric and non woven.

\section{References}

1. Mukheijee A, Ganguly PK, Sur D (1993) Structural Mechanics of Jute: The Effects of Hemicellulose or Lignin Removal. J Textile Institute 84: 348-353.

2. Joshia SV, Drzalb LT, Mohanty AK (2004) Arorac S Are natural fiber composites environmentally superior to glass fiber reinforced composites? Composites Part A 35: 371-376

3. Ghosh RK, Sreewongchai T, Nakasathien S, Phumichai C (2013) Phenotypic variation and the relationships among jute genotypes using morpho-agronomic traits and multivariate analysis. Australian Journal of Crop Science: 830-842.

4. Ali A (1989) Ultimate fibres in tossa jute (Corchures olitorius L.) and their utilization in selection Indian Acad Sci 99: 37-41.

5. Roe PJ, Ansell MP (1985) Jute-reinforced polyester composites.

6. Dash BN, Rana AK, Mishra HK, Nayak SK, Mishra SC, et al. (1999) Novel Low-cost jute-polyester composites Part-l: processing, mechanical properties and SEM analysis

7. Saha AK, Das S, Bhatta D, Mitra BC (1999) Study of Jute Fiber Reinforced Polyester Composites by Dynamic Mechanical Analysis. Journal of Applied Polymer Science 71: 1505-1513.

8. Ray D, Sarkar BK, Rana AK, Bos NR (2001) The mechanical properties of vinyl ester resin matrix composites reinforced with alkali treated jute fibres Composites Part A 32: 119.

9. Gassan J, Bledzki AK (1999) Alkali treatment of jute fibres Relationship between structure and mechanical properties. J Appl Polym Sci 71: 623.

10. Gassan J, Bledzki AK (1999) Possibilities for improving the mechanical properties of jute/epoxy composites by alkali treatment of fibers Comp Sci Tech 591303.

11. Tripathy SS, Dilandro LD, Fontanelli D, Marchetti A, Levita G (2000) Mechanical Properties of Jute Fibers and Interface Strength with an Epoxy Resin. Journal of Applied Polymer Science 75: 1585-1596.

12. Gowdaa TM, Naidu ACB, Chhayab R (1999) Some mechanical properties of untreated jute fabric-reinforced polyester Composites. Elsevier Science Ltd: 277-284.

13. Semsarzadeh MA, Lotfali AR, Mirzadeh H (1984) Jute-reinforced polyester structures. Polym Compos 5: 141

14. Doan TTL, Gao SL, Ma der E (2006) Jute/polypropylene composites I Effect of matrix modification Composites Science and Technology 66: 952-963.

15. Carvalho LHD, Cavalcante JMF, Almeida JRM (2006) Comparison of the Mechanical Behavior of Plain Weave and Plain Weft Knit Jute Fabric-PolyesterReinforced Composites. Polymer-Plastics Technology and Engineering 45 791-797. 
Citation: Das S, Bhowmick M (2015) Mechanical Properties of Unidirectional Jute-Polyester Composite. J Textile Sci Eng 5: 207. doi:10.4172/21658064.1000207

16. Khan MA, Haque N, Al-Kafi A, Alam MN, Abedin MZ (2006) Jute Reinforced Polymer Composite by Gamma Radiation Effect of Surface Treatment with UV Radiation Polymer-Plastics Technology and Engineering 45: 607-613.

17. Khan MA, Islam T, Rahman MA, Islam JM, Ruhul A, et al. (2010) Therma Mechanical and Morphological Characterization of Jute/Gelatin Composites Polymer-Plastics Technology and Engineering 49: 742-747.

18. Sultana S, Huque MM, Helali MM (2007) Studies on the Physicomechanical Properties of Sodium Periodate Oxidized Jute Reinforced Polypropylene (PP) Composites Polymer-Plastics Technology and Engineering 46: 385-391.
19. Reddy N, Yang Y (2011) Completely biodegradable soy protein-jute bio composites developed using water without any chemicals as plasticizer. Industrial Crops and Products 33: 35-41.

20. Behera AK, Avancha S, Sen R, Adhikari B (2013) Development and Characterization of Nanoclay-Modified Soy Resin-Based Jute Composite as an Eco-friendly/Green Product Polymer-Plastics Technology and Engineering 52: 833-840.

21. Saw SK, Akhtar K, Narendra Y, Singh AK (2014) Hybrid Composites Made from Jute/Coir Fibers Water Absorption Thickness Swelling Density Morphology and Mechanical Properties. J Natural Fibers 11: 39-53. 